\title{
The Permanent Court of Arbitration's Exegesis of the Regime of Islands and China's Nine-Dash-Line Claims in the South China Sea Arbitration
}

\author{
Theodore Okonkwo ${ }^{1, *}$ \\ ${ }^{1}$ Department of Public Law, Faculty of Law University of Port Harcourt, Port Harcourt, Nigeria \\ *Correspondence: Department of Public Law, Faculty of Law University of Port Harcourt, Port Harcourt, Nigeria. \\ E-mail: t161962@gmail.com
}

Received: September 22, 2017 Accepted: October 18, 2017 Online Published: November 8, 2017

doi:10.5430/wjss.v5n1p19 URL: https://doi.org/10.5430/wjss.v5n1p19

\begin{abstract}
The big South China Sea is one of the most dangerous hotspot in the world. By words and actions, there are six claimants of the South China Sea. The People's Republic of China and the Republic of the Philippines are some of them. Each want to control the numerous features and resources in boosting their economic interests. The United Nations was actively involved in the settlement of the disputes for their own security and economic interests. The great ownership question that comes about in this is the rightful owner of the South China Sea which involved the Nine-Dash Line claims by the government of the People's Republic of China, which laid claims to the Paracel Islands, the Spratly Islands, the Pratas Islands, the Maccles field Bank and the Scarborough Shoal. In the Arbitration between the two parties: China and Philippines, Annex VII of the United Nations Convention on the Law of the Sea was relied upon by the tribunal which gave award on $29^{\text {th }}$ October, 2015 on admissibility and jurisdiction. However the objection that was presented by China was rejected by the tribunal. This was because of the issue of the territorial sovereignty of China in the South China Sea which was not within the jurisdiction of the tribunal. The tribunal found interalia that the submission made by Philippines showed the dispute between the parties putting in mind the Convention interpretation and application. The requirements under article 283 of the Convention were met by the Philippines in regards to the settlement of the dispute. This paper examines the South China Sea arbitration award and the interpretation and the application of the regime of islands under article 121 of the United Nations Convention on the Law of the Sea.

Keywords: South China Sea, Article 121 of the United Nations Convention on the Law of the Sea, Peoples Republic of China, the Republic of the Philippines, economic life of their own, arbitration, tribunal, land territory, ownership, Nine-Dash Line
\end{abstract}

\section{Introduction}

One of the leading cases of environmental disputes in a new generation is the South China Sea Arbitration(Note 1). This dispute occurred on disputed maritime areas(Alexander 1986) of the Paracel Islands, the Spratly Islands, the Pratas Islands, the Macclesfield Bank and the Scarborough Shoal. The Philippine blamed China for environmental violations and claimed that China used harmful fishing practices which were harmful to the sea. Their actions caused serious harm to the South China Sea(Joseph 1987) and (Wu 2013). The parties involved in this arbitration are the People's Republic of China and the Republic of the Philippines, each laid claim to the maritime rights and the entitlement in the sea of South China (Jagota, 1985). This dispute also involved the status of geographical features in the sea of South China and the lawfulness of the actions taken by China in the South China sea.

This article examines the propriety of the award with respect to the interpretation and application of the right of Islands under Article 121 of the United Nations Convention on the Law of the Sea.

\section{The South China Sea Arbitration Award}

South China Sea is semi-enclosed in the west of the Pacific Ocean. The area that the sea occupies is 3.5 million square kilometers (Erik, 2006). The sea is surrounded by a number of countries. To the west lie the Philippines, to 
the south lies China, to the east is Vietnam and to the north are Malaysia, Brunei, Singapore and Indonesia. The South China Sea has important functions that it plays. It is a shipping lane, fishing ground, has coral reef ecosystem that is highly bio-diversified and the belief that it holds useful resources like oiland gas (Stein, 2005). On the southern part of the South China Sea one finds Spratly Islands, the Pratas Islands, the Paracel Islands, the Macclesfield Bank and the Scarborough Shoal. These are small Islands and coral reefs which exist above and below the water. The Spratly Islandshas been bringing territorial disputes among the states surrounding South China Sea.

The United Nations Convention on the Law of the Sea1982 (Convention)(Note 2) was the basis of this arbitration. The parties to the Convention are the Philippines and China (United Nations, 2000) and (Drigot, 1982). On the $8^{\text {th }}$ May of 1984 the Philippines ratified the Convention and China on $7^{\text {th }}$ June 1996 (Fravel, 2008). This Convention was taken as the constitution for the oceans (UNCLOS(Note 3)) for it to offer solutions on issues that are related to the Law of the Sea(Note 4) (McDevitt, 2014). The total number of parties that have ratified the Law of the Sea are 168(Note 5) (Kraska 2016). Peaceful settlement of disputes is one of the issues that the Convention addressed. Part $\mathrm{XV}$ of the Convention(Note 6) provides different ways of settling the disputes in a peaceful manner (Tonneson, 2010). It is compulsory for a party to follow the arbitration procedure that is in the Annex VII(Note 7) (Dinh, 2016). The Philippines embarked on this arbitration against China on the $22^{\text {nd }}$ of January, 2013. The sovereignty of States over the territory of land is not addressed in the Convention(Note 8), as a result, the tribunal involved in the ruling did not make ruling associated with the sovereignty that a state enjoys in the land territory. This is putting into account the dispute over Spratly Islands(Allison 2016). The Convention contain provisions that are concerned with delimitation of maritime boundaries(Note 9). A declaration was made by China in 2006 to separate maritime boundary delimitation from being accepted as being compulsory (Ikeshima, 2014) in the settlement of disputes(Note 10). The tribunal did not delimit issues concerning maritime boundaries between the parties (Beech, 2016). This will be addressed if the parties involved are not dependent on any of the maritime boundaries (Beckman, 2016).

The declarations that the Philippines placed before the tribunal are in four categories. The first one is that they had asked the tribunal to deal with the dispute between the parties that were concerned with the source of maritime rights and the entitlement of the South China Sea (Hu and McDorman, 2013). The Philippines were seeking a declaration (Boon, 2014) from the tribunal of the rights and entitlements of China to South China Sea. The declaration should be based on the Convention and not claims of historical rights(Ikishema, 2013) and (Stephens, 2016). The declaration that the Philippines sought is that the claim by China to the rights that are marked on Chinese maps, nine-dash line(Note 11), have no lawful effects for them to exceed the ownership that could be given to China by the Convention (Coleman andMaogoto, 2013)

The second category is the tribunal was asked by the Philippines to resolve the issue between the Philippines and China concerning entitlements to the maritime zones that will be gotten from the Convention by Scarborough Shoal(Note 12) and the maritime features of the Spratly Islands that both the parties claimed to own (Noyes, 2016). According to the Convention (Aust, 2010) the low-tide elevations and submerged banks are ineffective in generating rights of ownership to the maritime areas considering that they are rocks (Noyes, 2016) that cannot sustain the habitation of human beings or even economic life while left alone. This means that they cannot generate an ownership to a separate economic zone(Talmon, 2014). In this case, the declaration that the Philippines seeks is all the features that China claims in the Island of Spratly and the Scarborough Shoal is part of the categories that there is no feature that generates an entitlement to a shelf in the continent or an economic zone(Cheng, 2015).

The third category is the Philippines asking the tribunal to settle the disagreements between the two parties on the ground that China supported the action of the South China Sea(Rapp-Hooper, 2016). The Philippines also sought declaration that China has violated the Convention in a number of ways(Merills, 2011). The first one is the interference with the Philippines rights according to the Convention (Tzanakopoulos, 2016). This is putting into consideration fishing, the exploration of oil and the construction and installation of artificial islands(Strate, 2006). The second one is the failure of protecting and preserving the marine environment(Zhang, 2017). According to Ikeshima (2015) this is through tolerating and supporting the fishermen from China who harvests the endangered species while using fishing method that are harmful: they damage the coral reef ecosystem that is fragile in the sea. The third one is the severe harm that was inflicted on the marine environment through the construction of islands that are artificial and the reclamation of the Spratly Islands at the seven reefs (Ikeshima, 2017).

The fourth category is the tribunal being asked by the Philippines to hold that China has been escalating the dispute that exists between the two parties when the arbitration was taking place (Liu, 2016). According to (Wang 2017) they restricted access to the detachment of the marines belonging to the Philippines which were stationed at Second Thomas Shoal. They also engaged in the construction of islands that were artificial (Frankx and Benatar, 2012). 
However, China has continuously not accepted the Philippines stand on the arbitration and did not follow the proceedings by not accepting and participating in the proceedings (Swaine, 2016). This has been shown in many articulations of public statements and also Notes Verbales(Note 13) that are diplomatic(Baumert and Melchior, 2014). These were addressed to the Philippines and Permanent Court of Arbitration(Note 14) which is a registry for the arbitration between the twoparties(Morton, 2016). The Foreign Ministry of China(Note 15) has given statements, interviews and press briefings on their view of not being participants in the arbitration (Daugirdasand Mortenson, 2014). Mostly they claim that it is their lawful right which is in the Convention. The Convention addresses the issue of a party deciding not to participate (Talmon, 2016) in the proceedings of resolving a dispute in Article 9 of Annex VII(Note 16). According to the tribunal, considering that China is not willing to participate will not hinder the continuation of the arbitration (You, 2008). China remains a party to the arbitration according to the tribunal(Owen and Schofield, 2012). This is according to Article 296 of the Convention and Annex 11(Note 17) (Oanta, 2014). Though a party is not participating, the tribunal is given a special responsibility (United Nations, 1995). The tribunal in this case cannot accept the claims by the Philippines in the absence of China and give a default judgment(Rosenne, 1995). The tribunal should satisfy itself according to the requirements of Article 9(Note 18) on making judgments on such arbitrations (Wolfrum 2008).

There are steps that China took to show its view that the tribunal does not have jurisdiction to put the claims of the Philippines into consideration. In the year 2014, the Foreign Ministry of China published a Paper on their view of the tribunal called China's Position Paper(Note 19).China gave the arguments that the tribunal lacked jurisdiction because of a number of reasons(Note 20) (Mensah, 2004). The first one was the subject matter of the jurisdiction being territorial ownership of the South China Sea especially the maritime features (Esposito, 2011). The second one was the two parties had agreed to settle the disputes through negotiations (Tuerk, 2015). This agreement was made through bilateral instruments and Declaration of the conduct of the parties in the arbitration(Klein and Tanaka, 2014). The last one was the disputes which were submitted by the Philippines not constituting the most important part of maritime delimitation between the two parties (Toman, 2016). The Ambassador of China to Netherlands had made a number of communications to the tribunal members. This was done either directly or through the Registry. The purpose of the communications was to give statements of the officials of the Foreign Ministry and gain the attention of the arbitrators. The Ambassador made clear that these communications should not be taken as a way of China participating in the proceedings(Symmons, 2016).

The Position Paper and the communications by China were treated as by the tribunal as a plea by China for the jurisdiction. This was taken as an objection to the jurisdiction and the tribunal needed to separate a hearing to rule on the jurisdiction(Jones, 2016). This was replied by the tribunal through objecting the jurisdiction set out in the Position Paper by China. The tribunal in the Award of the jurisdiction made decisions while putting into considerations seven of the fifteen submissions which were made by the Philippines (Ndi, 2016). Other seven submissions were put aside for later considerations. The tribunal asked the Philippines to give clarifications on the remaining submission.

\section{The Interpretation and Application of the Regime of Islands under Article 121 of the United Nations Convention on the Law of the Sea}

The Spratly Islands and Scarborough Reef were the central issue in the arbitration that was presented by the Philippines against the People's Republic of China (Beckman, 2013), and (Dupuy, F.and Dupuy, P., 2013). This was submitted under the United Nations Convention on the Law of the Sea. Article 121 of the United Nations Convention on the Law of the Sea contains the regime of islands. The article defines an island as an area of land that was naturally formed, being surrounded by water and the land is above the water at high tides. Paragraph two of the article gives an explanation of islands having the same entitlements to maritime zones just like the other land territories. There is an exception to the rule that is provided in the third paragraph. It says that rocks that are not able to support human habitation or any economic life in their own way will not have exclusive economic zone and continental shelf. However the Convention does not interpret the terms 'rocks', 'human habitation' and 'economic life'. The scope of the application of the paragraph is therefore not clearly established.

The merit of the award in the arbitration of China and Philippines gave a review that was detailed in the interpretation and application of article 121. The Award gave clarifications that respected the third paragraph of the article for example, in the conclusion of the award the term rock is explained as not having the intention of limiting the scope of the decisions to given islands and excluding others like the islands that are composed with sand. According to the observation of the tribunal by limiting the term 'rocks' to the contents of a rock can result to the 
understanding of them being more ephemeral than geological rocks. This shows that their location may be shifted, by appearing and disappearing above the high waters. Another clarification that article 121 made was the findings that the rocks cannot change into an entitled island(Note 21).

There are a number of merits in some of the findings of the tribunal on article 121 . The award concentrated on two aspects that were critical. Firstly, the conclusion of the tribunal that the size cannot be a feature of status and be entitled as a rock and island when it is not a relevant issue was a merit (GaoandJia, 2013). Secondly the interpretation that the tribunal offered on the defining of 'economic life of their own' showed it was meaningless(Miyoshi 2012), (Gau 2012), (Keyuan 2012) and (Beckman and Schofield (2014). We shall examine these two aspects and how the tribunal approached them in the arbitration between China and the Philippines.

\section{a) The importance of the size of an island in article 121}

On reaching the conclusion that size is not related to the settlement of the dispute(Hu, 2010) and (Yee, 2014), the tribunal stated that if this was put into consideration, some of the islands would never be included in this article because some of them are big enough to be considered as rocks. Travauxpreparatories(Note 22) of the Convention is where the tribunal concentrated on. These were the supplementary means in the interpretation(Mincai, 2014). There were attempts of defining or categorizing the islands and rocks during UNCLOS III(Note 23) which were rejected(Smith, 2010). The tribunal in this ruling did not depend on the approach that was interpreted because they claimed that the approach was based on the Vienna Convention on the Law of Treaties(Note 24) (Elferink, 2001). According to the interpretation of article 31 of the Vienna Convention, a treaty (Keyuan, 1999) should be interpreted in good faith according to the ordinary meaning. The meaning should be given to the terms used in the treaty in what they mean considering its purpose and object(Thang and Thao, 2012).

In considering whether size is relevant in the determination of the status of an island in article 121, the analysis of the tribunal does not begin in establishing the normal meaning of the term rock (Beckman, 2011). This is different from the considerations of the tribunal (Greenfield, 1992). In determining the scope of the application of paragraph 3the size is relevant. The tribunal made use of the Oxford English Dictionary(Note 25) in the definition (Batongbacal, 2011). This was a starting point in establishing if the size is important in determining the meaning of 'rock'. The Oxford English Dictionary gives a number of meanings of the word rock (Dzurek, 1996) which explains that the word is used to refer to something with limited dimensions. The first description provides that it is a mass of rock that is projected above the surface of the earth or out of the sea(Note 26). This gives an understanding of the rocks being differentiated from the islands(Zou, 2013). The difference between the rocks and islands (Song and Zou, 2016) is also provided in article 121. Paragraph 1 talks about islands while paragraph 3 talks about rocks (Redd, 2009). If the drafters of the Convention had the intention of size not being relevant under the third paragraph making it applicable to all the islands, the same term could be used in the two paragraphs(Schofield, 2009). This is not the same in article 121.

\section{b) Interpretation of economic life of their own}

There are two conditions that article 121 contains to make a rock to be fully entitled as an island (Elferink, 2016). This is if it can sustain human habitation or an economic life of its own (Song and Tønnesson, 2013). The question that arises is whether the use of the word "or" in the phrase can be taken to mean the combination of the two phrases. This shows that a rock has to be able to sustain human habitation and the economic life or each of the two phrases separately to escape the explanation of article 121(Chen, 2016). The tribunal made conclusions that the two phrases are different but made a caveat that was critical by observing that the economic activities are carried out by human beings and it is hard to find people living in areas with no economic activities (Joyner, 1998), (Fravel, 2011), (Furtado, 1999) and(Dupuy, 2012). The two phrases are related to the practical terms of their meaning.

The interpretations of economic life by the tribunal are given in paragraph 543 and 547 of the award(Blood-Patterson, 2013). The two paragraphs show that the explanation requires a local population to be present in an area(Zimmerman and Baumler, 2013) Paragraph 543 includes the requirements of humans inhabiting an area (Beckan, 2015). This is because economic life of their own matches human habitation. However, during the first tribunal the use of the word 'or' between the phrases explained that the requirements are not required at the same time.

The phrase is broken into two by the tribunal namely; "economic life" and "of their own" (Emmers, 2014). The common meaning of the word economic is related to the regulation and developments in a community in terms of material resources. This also means the processes of producing goods and services. The word life means the presence of resources being insufficient and levels of human activities to exploit the resources. The word sustain should be put into consideration while reading 'economic life' according to the tribunal (Dutton, 2011). This shows that the 
economic activity has to be an ongoing process. There was no imported reference to the word value that the drafters used.

'Of their own' brings a clear definition of the feature having the ability of supporting an economic life that is independent (Hong, 2012). This is without relying on other resources from outside. According to the view of the tribunal, for an economic activity to include the feature of an economic life, the resource that the economic activity is surrounding should be local and not gotten from outside the area. The resource should be beneficial to the surrounding community. If an economic activity depends on resources from outside, it is not under 'an economic life of their own'. Also an economic activity that does not depend on the feature is not included in this. The explanation given by the tribunal on 'economic life' shows that the activity does not have to be permanent but can be carried over a given period of time in an area. This is explained in paragraph 500 of the award which looked at 'of their own' (Symmons, 2008).

\section{Conclusion}

It is evident that arbitration awards are a substitute means of settling a dispute. There is no specified formal procedure that the tribunal should follow. The decisions that the tribunal makes are not binding to other parties that may be involved in disputes in the future irrespective of if they appear before the same tribunal. Another tribunal is not bound to follow the South China Sea Arbitration and interpretations. The tribunals are not required to be consistent. This explains why the arbitration of the South China Sea interpretation was not persuaded in using article 128 that was applied in Southern Bluefin Tuna Arbitration.

The interpretations of the tribunal involved in the South China Sea dispute depending on article 121did not use the definition of the terms according to the international courts or other jurisdictions. Some of the terms are rocks and economic life of their own.

\section{References}

Alexander L. M. (1986). The delimitation of maritime boundaries. Political geography quarterly, 5, 1-2. https://doi.org/10.1016/0260-9827(86)90006-6

Allison, G. (2016). Of Course China, Like All Great Powers, Will Ignore an International Legal Verdict. The Diplomat, 11.

Aust, A. (2010). Handbook of International Law. Cambridge University Press. https://doi.org/10.1017/CBO9780511841460

Batongbacal, J. L. (2001). The Maritime Territories and Jurisdictions of the Philippines and the United Nations Convention on the Law of the Sea. Phil. LJ, 76, 123.

Baumert, K., \& Melchior, B. (2014). "China: Maritime Claims in the South China Sea". Report and Analysis Made for Office of Ocean and Polar Affairs Bureau of Oceans and International Environmental and Scientific Affairs, US Department of State.

Beckman, R. (2011). China, UNCLOS and the South China Sea. In Asian Society of International Law Third Biennial Conference.

Beckman, R. (2013). The UN Convention on the Law of the Sea and the Maritime Disputes in the South China Sea. American Journal of International Law, 107(1), 142-163. https://doi.org/10.5305/amerjintelaw.107.1.0142

Beckman, R. (2016). Game Changer in the Maritime Disputes. Routlegde.

Beckman, R. C. (2015). “The Philippines v. China Case and the South China Sea Disputes". In Territorial Disputes in the South China Sea (pp. 54-65). Palgrave Macmillan UK. https://doi.org/10.5305/amerjintelaw.107.1.0142

Beckman, R. C., \& Schofield, C. H. (2014). Defining EEZ Claims from Islands: A Potential South China Sea Change. The International Journal of Marine and Coastal Law, 29(2), 193-243. https://doi.org/10.1163/15718085-12341321

Beech, H. (2016). Just Where Exactly Did China Get the South China Sea Nine-Dash Line From?. Time Magazine.

Blood-Patterson, N. E. (2013). Smoke on the Water: The Role of International Agreements in the Philippine-Chinese Dispute over the South China Sea. NYUJ Int'l L. \& Pol., 46, 1207. 
Boon, K. E. (2014). International Arbitration in Highly Political Situations: the South China Sea Dispute and International law. Wash. U. Global Stud. L. Rev., 13, 487.

Chen, C. I. (2016). Legal Aspects of the ROC's Position on the U-Shaped Line. Prospect Journal, 15, 1-27.

Cheng, D. (2015). China's War AgainstInternational Law in the South China Sea. National Interest, 19.

Coleman, A., \& Maogoto, J. N. (2013). Westphalian" Meets "Eastphalian" Sovereignty: China in a Globalized World. Asian Journal of International Law, 3(2), 237-269. https://doi.org/10.1017/S2044251313000179

Daugirdas, K., \& Mortenson, J. D. (2014). United States Questions Claims Based on China's "Nine-Dash Line" in the South China Sea. American Journal of International Law, 108(2), 331-334.

Dinh, J. L. (2016). China's Dilemma in the South China Sea and the Arbitration Tribunal-Implications on China's Regional Strategy in Southeast Asia. International Journal of China Studies, 7(3), 301.

Drigot, D. C. (1982). Oil Interests and the Law of the Sea: The Case of the Philippines. Ocean Development \& International Law, 12(1-2), 23-70. https://doi.org/10.1080/00908328209545703

Dupuy, F., \& Dupuy, P. M. (2013). A Legal Analysis of China's Historic Rights Claim in the South China Sea. American Journal of International Law, 107(1), 124-141. https://doi.org/10.5305/amerjintelaw.107.1.0124

Dupuy, F. (2012). A Legal Analysis of China's Historic Rights Claim in the South China Sea. American Journal of International Law, 107, 124-131.

Dutton, P. (2011). Three Disputes and Three Objectives: China and the South China Sea. Naval War College Review, 64(4), 42.

Dzurek, D. J. (1996). The Spratly Islands Dispute: Who's on First?.Ibru.

Elferink, A, O (2016). The South China Sea Arbitration's Interpretation of Article 121(3) of the LOSC: A Disquieting First. Retrieved from http://site.uit.no/jclos/files/2016/09/The-South-China-Sea-Arbitrations-Interpretation-of-Article-1213-of-the-LO SC-A-Disquieting-First.pdf

Elferink, A. G. O. (2001). The Islands in the South China Sea: How Does Their Presence Limit the Extent of the High Seas and the Area and the Maritime Zones of the Mainland Coasts? Ocean Development \& International Law, 32(2), 169-190. https://doi.org/10.1080/00908320151100307

Emmers, R. (2014). ASEAN's Search for Neutrality in the South China Sea. Asian Journal of Peacebuilding, 2(1), 61.

Erik, K (2006). South China Sea. Retrieved from http://www.eia.doe.gov/emeu/cabs/South_China_Sea/pdf.pdf

Espósito, C. (2011). Advisory Opinions and Jurisdiction of the International Tribunal for the Law of the Sea. Social Science Electronic Publishing, 14(7), 149-75.

Franckx, E., \& Benatar, M. (2012). Dots and Lines in the South China Sea: Insights from the Law of Map Evidence. Asian Journal of International Law, 2(1), 89-118. https://doi.org/10.1080/00908320151100307

Fravel, M. T. (2008). Strong Borders. Secure Nation: Cooperation and Conflict in China's Territorial Disputes (Princeton: Princeton University, 2008). https://doi.org/10.1515/9781400828876

Fravel, M. T. (2011). China's Strategy in the South China Sea. Contemporary Southeast Asia: A Journal of International and Strategic Affairs, 33(3), 292-319. https://doi.org/10.1355/cs33-3b

Furtado, X. (1999). International Law and the Dispute Over the Spratly Islands: Whither UNCLOS?. Contemporary Southeast Asia, 386-404. https://doi.org/10.1355/CS21-3D

Gao, Z., \& Jia, B. B. (2013). The Nine-Dash Line in the South China Sea: History, Status, and Implications. American Journal of International Law, 107(1), 98-123. https://doi.org/10.5305/amerjintelaw.107.1.0098

Gau, M. S. T. (2012). The U-Shaped Line and a Categorization of the Ocean Disputes in the South China Sea. Ocean Development \& International Law, 43(1), 57-69. https://doi.org/10.1080/00908320.2012.647499

Greenfield, J. (1992). China's Practice in the Law of the Sea. Clarendon Press.

Hong, N. (2012). UNCLOS and Ocean Dispute Settlement: Law and Politics in the South China Sea. Routledge.

Hu, N. T. A. (2010). South China Sea: Troubled Waters or a Sea of Opportunity?. Ocean Development \& International Law, 41(3), 203-213. https://doi.org/10.1080/00908320.2010.499312 
Hu, N. T. A., \& McDorman, T. L. (Eds.). (2013). Maritime Issues in the South China Sea: Troubled Waters Or a Sea of Opportunity. Routledge.

Ikeshima, T. (2013). China's Dashed Line in the South China Sea: Legal Limits and Future Prospects". In Waseda Global Forum (No. 10, pp. 17-50).

Ikeshima, T. (2014). Applicability of the Law of the Sea in the Settlement of Territorial and Maritime Disputes in the East and South China Seas. WasedaGlobal Forum, 11, 47-73).

Ikeshima, T. (2015). China's Air Defense Identification Zone (ADIZ) and its Impact on the Territorial and Maritime Disputes in the East and South China Seas. Transcommunication, 3(1), 151-170.

Ikeshima, T. (2017). "Fundamental Pitfalls of the South China Sea Arbitration Ruling". In Waseda Global Forum (No. 13).

Jagota, S.P. (1985) Maritime Boundary. Dordrecht; Boston: MartinusNijhoff Publishers.

Jones, J. L. (2016). Free the Sea: The Philippines v. China. SAIS Review of International Affairs, 36(1), 75-86. https://doi.org/10.1353/sais.2016.0001

Joseph, D, A. (1987). The Exclusive Economic Zone in International Law. Oxford: Clarendon Press; New York: Oxford University Press.

Joyner, C. C. (1998). The Spratly Islands Dispute: Rethinking the Interplay of Law, Diplomacy, and Geo-Politics in the South China Sea. The International Journal of Marine and Coastal Law, 13(2), 193-236. https://doi.org/10.1163/15718089820491980

Keyuan, Z. (1999). The Chinese Traditional Maritime Boundary Line in the South China Sea and Its Legal I Consequences for the Resolution of the Dispute over the Spratly Islands. The International Journal of Marine and Coastal Law, 14(1), 27-55.

Keyuan, Z. (2012). China's U-Shaped Line in the South China Sea Revisited. Ocean Development and International Law, 43(1), 18-34. https://doi.org/10.1080/00908320.2012.647483

Klein, N., \& Tanaka, Y. (2014). "The Dispute Settlement System of the United Nations Convention on the Law of the Sea: An Assessment after 20 Years". In Proceedings of the Annual Meeting-American Society of International Law (No. 108, p. 359). American Society of International Law.

Kraska, J. (2016). "Forecasting the South China Sea Arbitration Merits Award". Retrieved from maritimeawarenessproject.org/2016/04/27/forecasting-thesouth-china-sea-arbitration-merits-award/

Liu, Z. (2016). Questions of Neutrality: China Takes Aim at Judges in South China Sea Case. South China Morning Post 11 .

McDevitt, M. (2014). The South China Sea: Assessing US Policy and Options for the Future. CNA Occasional Paper). Arlington, VA: Center for Naval Analysis.

Mensah, T. A. (2004). The Significance of the International Tribunal for the Law of the Sea for the Shipping Industry. WMU Journal of Maritime Affairs, 3(2), 111-121. https://doi.org/10.1007/BF03195054

Merrills, J. (2011). International Dispute Settlement. Cambridge University Press. https://doi.org/10.1017/CBO9780511973550

Mincai, Y. (2014). China's Responses to the Compulsory Arbitration on the South China Sea Dispute: Legal Effects and Policy Options. Ocean Development and International Law, 45(1), 1-16. https://doi.org/10.1080/00908320.2014.867190

Miyoshi, M. (2012). China's "U-Shaped Line" Claim in the South China Sea: Any Validity Under International Law?. Ocean Development and International Law, 43(1), 1-17. https://doi.org/10.1080/00908320.2011.619374

Morton, K. (2016). China's Ambition in the South China Sea: is a Legitimate Maritime Order Possible?. International Affairs, 92(4), 909-940. https://doi.org/10.1111/1468-2346.12658

Natalie, K. (2005). Dispute Settlement in the UN Convention on the Law of the Sea. Cambridge University Press.

Ndi, G. K. (2016). Philippines v China: Assessing the Implications of the South China Sea Arbitration. Australian Journal of Maritime and Ocean Affairs, 8(4), 269-285. https://doi.org/10.1080/18366503.2016.1244142

Noyes, J. E. (2016). In re Arbitration between the Philippines and China. American Journal of International Law, 110(1), 102-108. https://doi.org/10.5305/amerjintelaw.110.1.0102 
Noyes, J. E. (2016). United Nations Convention on the Law of the Sea-Jurisdiction and Admissibility-Nonparticipation of a Party-South China Sea Claims, Activities, and Maritime Features: IN RE ARBITRATION BETWEEN THE PHILIPPINES AND CHINA. PCA Case No. 2013 19. Jurisdiction and Admissibility. At http://www. pca-cpa.org. UN Convention on the Law of the Sea Annex VII Arbitral Tribunal, October 29, 2015. AJIL, 110, 102-415.

Oanta, G. A. (2014). The International Tribunal for the Law of the Sea and the Polar Regions. The Law and Practice of International Courts and Tribunals, 13(3), 286-305. https://doi.org/10.1163/15718034-12341278

Owen, N. A., \& Schofield, C. H. (2012). Disputed South China Sea Hydrocarbons in Perspective. Marine Policy, 36(3), 809-822. https://doi.org/10.1016/j.marpol.2011.11.010

Pemmaraju, S. R. (2016). The South China Sea Arbitration (The Philippines v. China): Assessment of the Award on Jurisdiction and Admissibility. Chinese Journal of International Law, 15(2), 265-307. https://doi.org/10.1093/chinesejil/jmw019

Prolss, A. (2017). United Nations Convention on the Law of the Sea: A Commentary. Hart. https://doi.org/10.5771/9783845258874

Ralph, C. (1979). The Maritime Zones of Islands in International Law. BRILL.

Rapp-Hooper, M. (2016). Parting the South China Sea: How to Uphold the Rule of Law. Foreign Aff., 95, 76.

Redd, T. (). Competing Claims in the South China Sea: Is There an Equitable Solution?.

Roach, A., \& Smith, R. (2012). Excessive Maritime Claims (3rd Ed.). Martinus Nijhoff Publishers. https://doi.org/10.1163/9789004217720

Rosenne, S. (1995). The United Nations Convention on the Law of the Sea, 1982. Isr. L. Rev., 29, 491. https://doi.org/10.1017/S0021223700014734

Rothwell, D. (2015). The Oxford Handbook of the Law of the Sea. Oxford University Press.

Schofield, C. (2009). The Trouble WithIslands: the Definition and Role of Islands and Rocks in Maritime Boundary Delimitation. In Maritime Boundary Disputes, Settlement Processes, and the Law of the Sea (pp. 19-38). Brill. https://doi.org/10.1163/ej.9789004173439.i-308.13

Smith, R. W. (2010). Maritime Delimitation in the South China Sea: Potentiality and Challenges. Ocean Development \& International Law, 41(3), 214-236. https://doi.org/10.1080/00908320.2010.499315

Song, Y. H., \& Tønnesson, S. (2013). The Impact of the Law of the Sea Convention on Conflict and Conflict Management in the South China Sea. Ocean Development and International Law, 44(3), 235-269. https://doi.org/10.1080/00908320.2013.808935

Song, Y. H., \& Zou, K. (2016). Major Law and Policy Issues in the South China Sea: European and American Perspectives. Routledge.

Stein, T (2005). Locating the South China Sea. In Locating Southeast Asia: Geographies of Knowledge and Politics of Space, edited by Paul Kratoska, Henk Schulte Nordholt and RemcoRaben, 203-33: Ohio University Press.

Stephens, T. (2016). The International Law of the Sea. Bloomsbury Publishing.

Strate, A. (2006). Unresolved Issues And New Challenges to the Law of the Sea: Time Before And Time After. MartinusNijhoff Publishers.

Swaine, M. D. (2016). Chinese Views on the South China Sea Arbitration Case between the People's Republic of China and the Philippines. China Leadership Monitor, 51.

Symmons, C. R. (2008). Historic Waters in the Law of the Sea (p. 68). Boston, MA: MartinusNijhoff Publishers.

Symmons, C. R. (2016, March). "Historic Waters and Historic Rights in the South China Sea: A Critical Appraisal". In UN Convention on the Law of the Sea and the South China Sea (Vol. 24, p. 191). Routledge.

Talmon, S. (2016). The South China Sea Arbitration: Observations on the Award on Jurisdiction and Admissibility". Chinese Journal of International Law, 15(2), 309-391. https://doi.org/10.1093/chinesejil/jmw025

Talmon, S. A. (2014). The South China Sea Arbitration: Is There a Case to Answer?. The South China Sea Arbitration: A Chinese Perspective, edited by Stefan Talmon and Bing Bing Jia (Oxford: Hart Publishing, 2014), pp. 15-79. http://dx.doi.org/10.2139/ssrn.2393025 
Thang, N. D., \& Thao, N. H. (2012). China's Nine Dotted Lines in the South China Sea: The 2011 Exchange of Diplomatic Notes Between the Philippines and China. Ocean Development \& International Law, 43(1), 35-56. https://doi.org/10.1080/00908320.2012.647490

Toman, R. G. (2016). Jurisdictional Requirements for Arbitration under UNCLOS: Does the South China Sea Decision Bring Long Sought Clarity to the Scope of Historic Claims. NYUJ Int'l L. and Pol., 49, 619.

Tonneson, S. (2010, November). "Misperceptions, National Interests, and Law in the South China Sea". In paper at the international workshop on" The South China Sea: Cooperation for Regional Security and Development", Ho Chi Minh City.

Tuerk, H. (2015). "UNCLOS and the Contributions of ITLOS". In UN Convention on the Law of the Sea and the South China Sea (pp. 15-30). Ashgate Publishing, Ltd.

Tzanakopoulos, A. (2016). "Resolving Disputes Over the South China Sea Under the Compulsory Dispute Settlement System of the UN Convention on the Law of the Sea".

United Nations (2000). Division for Ocean Affairs and the Law of the Sea. Handbook on the Delimitation of Maritime Boundaries. (United Nations Publications.)

United Nations. (1995). Division for Ocean Affairs and the Law of the Sea.Law of the Sea Bulletin.

Wang, J. (2017). Legitimacy, Jurisdiction and Merits in the South China Sea Arbitration: Chinese Perspectives and International Law. Journal of Chinese Political Science, 22(2), 185-210. https://doi.org/10.1007/s11366-017-9472-0

Wolfrum, R. (2008). The Settlement of Disputes before the International Tribunal for the Law of the Sea. Japanese YB Int'l L., 51, 140.

Wu, S. (2013). Solving Disputes for Regional Cooperation and Development in the South China Sea: a Chinese Perspective. Elsevier. https://doi.org/10.1533/9781780633558

Wu, S. (2016). Arbitration Concerning the South China Sea: Philippines versus China. Routledge.

Yee, S. (2014). The South China Sea Arbitration (The Philippines v. China): Potential Jurisdictional Obstacles or Objections. Chinese Journal of International Law, 13(4), 663-739. https://doi.org/10.1093/chinesejil/jmu045

You, K. J. (2008). Advisory Opinions of the International Tribunal for the Law of the Sea: Article 138 of the Rules of the Tribunal, Revisited. Ocean Development and International Law, 39(4), 360-371. https://doi.org/10.1080/00908320802459128

Zhang, F. (2017). South China Sea Arbitration Award: Breathtaking (but Counterproductive).

Zimmermann, A., \& Bäumler, J. (2013). Navigating Through Narrow Jurisdictional Straits: The Philippines-PRC South China Sea Dispute and UNCLOS. The Law and Practice of International Courts and Tribunals, 12(3), 431-461. https://doi.org/10.1163/15718034-12341266

Zou, K. (2013). Law of the sea in East Asia: Issues and Prospects. Routledge.

\section{Notes}

Note 1. Philippine. v. China, PCA Case No. 2013-19, Award (July 12, 2016).

Note 2. Stein, T (2005). 'Locating the South China Sea.' In Locating Southeast Asia: Geographies of Knowledge and Politics of Space, edited by Paul Kratoska, Henk Schulte Nordholt and RemcoRaben, 203-33: Ohio University Press.

Note 3. With the adaption of the constitution for the oceans (1982) a comprehensive framework was put in place to govern the seas legally.

Note 4. The law provided rules that govern oceans (1958 and 1960).

Note 5. Kraska, J. (2016). 'Forecasting the South China Sea Arbitration Merits Award'. Accessed from: maritimeawarenessproject.org/2016/04/27/ forecasting-thesouth-china-sea-arbitration-merits-award/.

Note 6. States that when a state signs, ratifies or accedes to this Convention at a later time, it will choose by a writing declaration the method that the dispute will be settled (Article 287).

Note 7. Provide institutions of proceedings during arbitration.

Note 8. Pemmaraju, S. R. (2016). 'The South China Sea Arbitration (The Philippines v. China): Assessment of the 
Award on Jurisdiction and Admissibility'. Chinese Journal of International Law, 15(2), 265-307.

Note 9. Alexander, L, M (1986). 'The Delimitation of Maritime Boundaries'. Political Geography Quarterly 5. p. $1-2$.

Note 10. United Nations. Division for Ocean Affairs and the Law of the Sea.(2000). Handbook on the Delimitation of Maritime Boundaries. United Nations Publications.

Note 11. These are the demarcation lines that was used by the People's Republic of China for the claims of owning a major part of the South China Sea.

Note 12. Where China planned to build an environmental monitoring station.

Note 13. This is a note that is diplomatic and being more formal than a note which is also not signed and prepared in the third person.

Note 14. This was established through a treaty in the year 1899 to provide resolutions or disputes for the community, internationally.

Note 15. The position of the People's Republic of China government on matters of jurisdiction in the Arbitration of the South China Sea that was initiated by the Republic of the Philippines (2014). www.fmprc.gov.cn/mfa_eng/zxxx_662805/t1217147.shtml

Note 16. The absence of a party or failing to defend the case should not be a hindrance to the proceedings.

Note 17. A party not willing to actively participate in the tribunal shall be bound to the awards of the Tribunal.

Note 18. A Tribunal will not only have a jurisdiction over a dispute but claim that it is founded in fact and law.

Note 19. A Paper by the Government of the People's Republic of China about the jurisdiction in the South China Sea Arbitration.

Note 20. Mensah, T. A. (2004). 'The Significance of the International Tribunal for the Law of the Sea for the Shipping Industry'. WMU Journal of Maritime Affairs, 3(2), 111-121.

Note 21. This would frustrate the purpose of Article 121(3).

Note 22. These are the official records of a negotiation.

Note 23. The Third United Nations Conference on the Law of the Sea.

Note 24. It was adopted in the year 1969 on May $23^{\text {rd }}$.

Note 25. A descriptive dictionary that uses the English language.

Note 26. Accessed from Oxford English Dictionary online. 